\title{
Dopamine D4 receptor polymorphism and idiopathic Parkinson's disease
}

\author{
$M$ artina $\mathrm{F}$ K ronenberg ${ }^{1}, \mathrm{H}$ ans-J ürgen $\mathrm{M}$ enzel $^{2}$, G eorg $\mathrm{E}$ bersbach ${ }^{1}$, G regor $\mathrm{K}$ Wenning ${ }^{1}$, \\ E lisabeth L uginger ${ }^{1}$, M artin G ollner ${ }^{1}$, Gerhard R ansmayr ${ }^{1}$, G erd U termann², \\ Werner Poewe ${ }^{1}$ and Florian K ronenberg ${ }^{2}$ \\ ${ }^{1} D$ epartment of N eurology, Innsbruck U niversity H ospital \\ ${ }^{2}$ Institute of M edical Biology and H uman G enetics, U niversity of Innsbruck, A ustria
}

\begin{abstract}
Patients with idiopathic Parkinson's disease (IPD ) are described as having markedly decreased novelty seeking characteristics. Since recent publications suggest an association between the dopamine $\mathrm{D} 4$ receptor polymorphism and novelty seeking, we investigated this polymorphism in a group of 122 patients with IPD and 127 healthy control subjects. We found similar allele and genotype frequencies in both groups and no association with the age of onset of symptoms. Therefore, the dopamine D 4 receptor polymorphism does not confer genetic susceptibility to IPD and cannot explain the decreased novelty seeking in IPD patients.
\end{abstract}

Keywords: Parkinson's disease; dopamine receptor; dopamine D 4 receptor; polymorphism; susceptibility gene; association study; novelty seeking

\section{Introduction}

Recent studies have found an association between a polymorphism of the exon III repeat sequence of the dopamine $D 4$ receptor gene (D 4DR) and the trait of novelty seeking in normal volunteers. ${ }^{1-5}$ Individuals with long alleles of this polymorphism scored significantly higher in tests of novelty seeking than subjects with short alleles, supporting earlier suggestions that interindividual variation in novelty seeking might be mediated through genetic variability in dopaminergic transmission. ${ }^{6}$

Patients with idiopathic Parkinson's disease (IPD) are also reported to have markedly lower scores in tests

Correspondence: D r Florian K ronenberg, Institute of M edical Biology and Human Genetics, Schöpfstr. 41, A -6020 Innsbruck. Tel: +43 512507 3474; Fax: +43 512507 2861; E -mail: florian.kronenberg@uibk.ac.at

R eceived 17 July 1998; revised 220 ctober 1998; accepted 11 N ovember 1998 for novelty seeking compared with controls. ${ }^{7} \mathrm{~W}$ hilst this finding may be related to brain dopamine deficiency in $I P D$, an alternative hypothesis is that decreased novelty seeking in IPD patients is in part genetically determined by the D 4D R polymorphism. This could explain the frequently reported features of decreased novelty seeking in the premorbid Parkinsonian personality and raises the question whether $D 4 D R$ polymorphism may act as a genetic susceptibility gene for IPD. B eside the decreased novelty seeking in IPD patients, the D 4DR gene is a biologically reasonable candidate gene for the following reasons:

(i) the different alleles differently influence the binding of the ligand to the receptor which is higher for long alleles; ${ }^{8}$

(ii) D 4DR receptors show a particular concentration in the limbic system ${ }^{9}$ and

(iii) dopamine mediates the explorative behaviour at least in animal studies. ${ }^{10}$ 
For these reasons the present study was performed to compare D 4DR allele frequencies in a cohort of IPD patients and healthy controls.

\section{Subjects and Methods}

We investigated 122 ( 55 females and 67 males) unrelated Caucasian patients (age $68 \pm 10$ years) with IPD diagnosed according to the U K Parkinson's D isease Society B rain Bank (U K PD S B B ) criteria. ${ }^{11}$ Patients were recruited consecutively from our PD clinic and in-patient wards. W ritten informed consent was obtained from each patient. O ne hundred and twenty-seven healthy blood donors from the same geographical area served as control group.

G enomic DNA was extracted by standard procedures from whole blood. The $48 \mathrm{bp}$ repeat polymorphism at the third exon of the D 4D R gene ${ }^{9}$ was analysed by PCR amplification using the protocol and primers recently described. ${ }^{9} \mathrm{~L}$ aboratory personnel performing the genotyping were completely unaware of the patient/control status. Long D 4DR alleles consisted of six to eight $48 \mathrm{bp}$ repeats and short alleles of two to five repeats.

The Pearson's $\chi^{2}$ test and the likelihood-ratio $\chi^{2}$ test were used to compare the frequencies of D 4DR alleles and genotypes between patients and controls. Power analysis revealed that we have $80 \%$ power to detect a difference of $9 \%$ in the frequency of long alleles and $16 \%$ in the frequency of genotypes including at least one long allele. We compared the age at onset of the disease between subjects with at least one long allele and those with only short alleles by the unpaired t test.

\section{Results}

Table 1 shows the $D 4 D R$ allele frequencies in 122 patients with IPD and 127 healthy controls. There

Table 1 A llele frequencies of the D4DR gene polymorphism in 122 patients with idiopathic Parkinson's syndrome (IPD) and 127 control subjects

\begin{tabular}{|c|c|c|}
\hline D 4D R alleles & $\begin{array}{c}\text { IPD } \\
n=244 \text { alleles }\end{array}$ & $\begin{array}{c}\text { Controls } \\
n=254 \text { alleles }\end{array}$ \\
\hline allele 2 & 0.098 & 0.126 \\
\hline allele 3 & 0.054 & 0.055 \\
\hline allele 4 & 0.672 & 0.603 \\
\hline allele 5 & 0.000 & 0.031 \\
\hline allele 6 & 0.008 & 0.004 \\
\hline allele 7 & 0.156 & 0.173 \\
\hline allele 8 & 0.012 & 0.008 \\
\hline \multicolumn{3}{|l|}{ alleles combined $^{a}$} \\
\hline allele 2 -allele 5 & 0.824 & 0.815 \\
\hline allele 6 -allele 8 & 0.176 & 0.185 \\
\hline
\end{tabular}

'Pearson's $\chi^{2}$-test: $\chi^{2}=0.065, d f=1, p=0.80$. was no significant difference in the number of long alleles (alleles with six to eight $48 \mathrm{bp}$ repeats) between patients and controls. When we compared the genotype frequency between the two groups we observed a higher frequency of $4 / 4$ genotypes in the patient group which, however, did not reach significance $(43.4 \%$ vs $34.6 \%$ ) (Figure 1). The frequency of genotypes including at least one long allele was also similar in patients and controls ( $32.8 \%$ vs $33.9 \%)$.

Finally we compared the age at onset of symptoms of patients with at least one long allele with those having only short alleles. There was no significant difference for age at onset between the two patient groups ( $60 \pm 10$ vs $59 \pm 15$ years).

\section{Discussion}

There is growing evidence of significant genetic contribution to IPD. Recent studies proposed different genes for IPD in different families ${ }^{12-18}$ and it became apparent that several genes might be involved independently; for review see Nussbaum and Polymeropoulos. ${ }^{19}$

The present study investigated the $D 4 D R$ receptor polymorphism as another candidate for increased

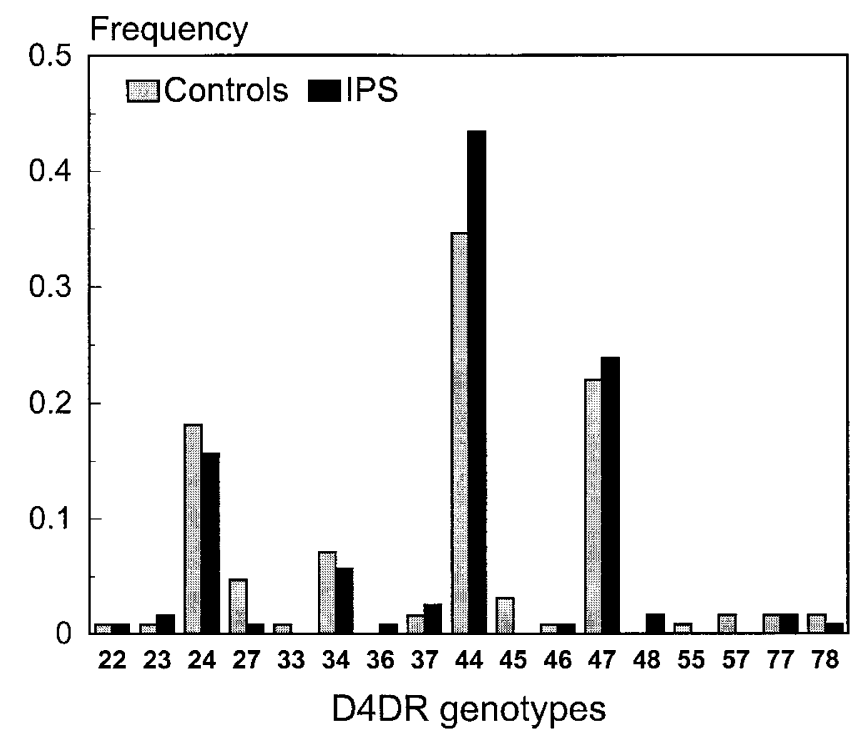

Figure 1 Frequencies of the dopamine D 4 receptor (D 4D R) genotypes in 122 patients with idiopathic Parkinson's disease (IPD) and 127 control subjects. The frequency distribution is not significantly different between patients and controls (by likelihood ratio $\chi^{2}$ test). 
genetic susceptibility to IPD because of its possible role in the expression of personality traits: short alleles were described in some ${ }^{1-5}$ but not all ${ }^{20-23}$ studies to be associated with decreased novelty seeking. This personality trait was found to be decreased in patients with $I P D^{7}$ and was regarded as part of their premorbid personality. ${ }^{24}$ To reduce a possible effect of gross motor impairment on the novelty seeking score in IPD patients, equally disabled orthopaedic and rheumatology patients served as controls in the study by $\mathrm{M}$ enza et al. $^{7}$

U sing a large group of patients with IPD we were neither able to show an association between the disease state itself nor the age at onset of symptoms and the D 4D R receptor polymorphism. It therefore seems that the $D 4 D R$ receptor gene is not a susceptibility gene for Parkinson's disease in the population we investigated. This is in contrast to a recent study of 92 IPD patients which reported a higher frequency of genotypes with long alleles compared with 47 controls. ${ }^{25} \mathrm{H}$ owever, the sample size, especially of the controls, raises doubts about the statistical power of this study. ${ }^{25} \mathrm{~A}$ further small study in a Japanese population was also unable to detect differences between IPD patients and controls in the D4DR polymorphism. ${ }^{26}$ However, a markedly different $D 4 D R$ allele distribution in Japanese control subjects with $\geq 98 \%$ short alleles s, $^{3,6,27}$ makes it difficult to detect a significant difference between patients and controls. This therefore justified the investigation of the polymorphism in IPD patients and controls of European origin where the frequency of short alleles is usually between $75 \%$ and $85 \% .{ }^{27}$

The association between the D 4DR polymorphism and novelty seeking was recently discussed controversially ${ }^{1-5,20-23}$ and has still to be determined. If there indeed exists an association, we conclude from the present study that the decreased novelty seeking in patients with IPD cannot be explained by this polymorphism since we observed similar allele and genotype frequencies in patients and controls.

O ur study, however, could be limited by not assessing novelty seeking in patients and controls and therefore not totally excluding a selection bias. The high number of patients, the consecutive recruitment, and the selection of a control group from the same geographical area might have minimised this possibility.

In summary, the similar D 4DR allele frequency in patients and controls suggests that this gene is not a susceptibility gene for Parkinson's disease and that the decreased novelty seeking in patients with IPD cannot be explained by genetic variation in the $D 4 D R$ receptor.

\section{Acknowledgements}

$\mathrm{F} \mathrm{K}$ ronenberg is supported by the Austrian Programme for A dvanced R esearch and Technology (A PART) of the A ustrian A cademy of Science. This study was supported by a grant from the Austrian Nationalbank (Project 5553). We thank Dr D Schönitzer (Institute for Blood Transfusion) for providing us blood samples from healthy blood donors and Silke Marenbach for technical assistance.

\section{References}

1 Ebstein RP, Novick O, U mansky R et al: Dopamine D 4 receptor (D 4DR ) exon III polymorphism associated with the human personality trait of novelty seeking. $\mathrm{N}$ at $\mathrm{G}$ enet 1996; 12: 78-80.

2 Benjamin J, Li L, Patterson C, Greenberg BD, M urphy $\mathrm{DL}, \mathrm{H}$ amer $\mathrm{DH}$ : Population and familial association between the $D 4$ dopamine receptor gene and measures of novelty seeking. $\mathrm{N}$ at $\mathrm{G}$ enet 1996; 12: 81-84.

$3 \mathrm{O}$ no $\mathrm{Y}, \mathrm{M}$ anki $\mathrm{H}, \mathrm{Y}$ oshimura $\mathrm{K}$ et al: A ssociation between dopamine D4 receptor (D4DR) exon III polymorphism and novelty seeking in J apanese subjects. A $\mathrm{m}$ J M ed G enet 1997; 74: 501-503.

4 Noble E P, OzkaragozTZ, R itchie TL, Z hang X, B elin TR, Sparkes RS: D 2 and D 4 dopamine receptor polymorphisms and personality. Am J Med Genet 1998; 81: 257-267.

5 E bstein R P, Nemanov L, K lotz I, G ritsenko I, Belmaker $\mathrm{RH}$ : A dditional evidence for an association between the dopamine D 4 receptor (D 4D R) exon III repeat polymorphism and the human personality trait of novelty seeking. M ol Psychiatry 1997; 2: 472-477.

6 Cloninger CR, Svrakic D M, Przybeck TR: A psychobiological model of temperament and character. A rch $G$ en Psych 1993; 50: 975-990.

7 M enza M A, G olbe LI, Cody R A, Forman N E : D opaminerelated personality traits in Parkinson's disease. Neurology 1993; 43: 505-508.

8 Van Tol H H, Wu CM, Guan HC et al: Multiple dopamine D 4 receptor variants in the human population. Nature 1992; 358: 149-152.

9 Van Tol H H M , B unzow J R, G uan H C et al: Cloning of the gene for human $D 4$ receptor with high affinity for the antipsychotic clozapine. Nature 1991; 350: 610-619.

10 Hooks MS, Kalivas PW: Involvement of dopamine and excitatory amino acid transmission in novelty-induced motor activity. J Pharmacol Exp Ther 1994; 269: 976-988.

11 H ughes A J, D aniel SE, K ilford L, Lees A J : A ccuracy of clinical diagnosis of idiopathic Parkinson's disease: a clinico-pathological study of 100 cases. J Neurol Neurosurg P sychiatr 1992; 55: 181-184.

12 Polymeropoulos M H, Lavedan C, L eroy E et al: M utation in the alpha-synuclein gene identified in families with Parkinson's disease. Science 1997; 276: 2045-2047. 
13 Yamamoto $\mathrm{M}$, Kondo I, O gawa $\mathrm{N}$, A sanuma $\mathrm{M}, \mathrm{Y}$ amashita $Y, M$ izuno $Y$ : $G$ enetic association between susceptibility to Parkinson's disease and $\alpha_{1}$-antichymotrypsin polymorphism. Brain Res 1997; 759: 153-155.

14 G asser T, Muller-M yhsok B, W szolek ZK et al: A susceptibility locus for Parkinson's disease maps to chromosome 2p13. N at G enet 1998; 18: 262-265.

15 B andmann O, Vaughan J, H olmans P, M arsden CD, Wood NW: A ssociation of slow acetylator genotype for $\mathrm{N}$-acetyltransferase 2 with familial Parkinson's disease. L ancet 1997; 350: 1136-1139.

16 K rüger $\mathrm{R}$, K uhn W, M üller T et al: A la30Pro mutation in the gene encoding alpha-synuclein in Parkinson's disease [letter]. Nat G enet 1998; 18: 106-108.

17 Planté-B ordeneuve $V$, Taussig D, Thomas $F$ et al: E valuation of four candidate genes encoding proteins of the dopamine pathway in familial and sporadic Parkinson's disease: evidence for association of a DRD2 allele. Neurology 1997; 48: 1589-1593.

18 Nakatome $M$, Tun Z, Shimada S, H onda K : D etection and analysis of four polymorphic markers at the human monoamine oxidase (MAO) gene in Japanese controls and patients with Parkinson's disease. Biochem Biophys Res Commun 1998; 247: 452-456.

19 N ussbaum RL, Polymeropoulos M H: G enetics of Parkinson's disease. H um M ol G enet 1997; 6: 1687-1691.

20 J önsson E G, N öthen M M, Gustavsson JP et al: Lack of evidence for allelic association between personality traits and the dopamine $\mathrm{D} 4$ receptor gene polymorphisms. A $\mathrm{m} J$ Psychiatry 1997; 154: 697-699.
21 G elernter J, Kranzler H, Coccaro E, Siever L, N ew A, M ulgrew CL : D 4 dopamine-receptor (DRD 4) alleles and novelty seeking in substance-dependent, personality-disorder, and control subjects. A m J H um G enet 1997; 61: $1144-1152$.

22 Pogue-G eile M, Ferrell R, D eka R, D ebski T, M anuck S: $H$ uman novelty-seeking personality traits and dopamine D 4 receptor polymorphisms: a twin and genetic association study. A m J M ed G enet 1998; 81: 44-48.

23 Vandenbergh D J, Z onderman A B, Wang J, U hl G R, Costa PT J r: No association between novelty seeking and dopamine D4 receptor (D 4DR) exon III seven repeat alleles in Baltimore Longitudinal Study of A ging participants. M ol Psychiatr 1997; 2: 417-419.

24 Poewe W, Gerstenbrand F, R ansmayr G, Plorer S: Premorbid personality of Parkinson patients. J N eural Transm 1983; 19 Suppl.: 215-224.

25 Ricketts $\mathrm{M} \mathrm{H}, \mathrm{H}$ amer $\mathrm{R} M$, $M$ anowitz $\mathrm{P}$ et al: A ssociation of long variants of the dopamine D 4 receptor exon 3 repeat polymorphism with Parkinson's disease. Clin G enet 1998; 54: 33-38.

26 Nanko S, U eki A, Hattori $\mathrm{M}$ et al: $\mathrm{No}$ allelic association between Parkinson's disease and dopamine D 2, D 3, and D 4 receptor gene polymorphisms. A m J M ed G enet 1994; 54: 361-364.

27 Chang FM, Kidd J R, Livak KJ, Pakstis A J, Kidd K K: The world-wide distribution of allele frequencies at the human dopamine D4 receptor locus. Hum Genet 1996; 98: 91-101. 